\title{
起声時に括ける病的発声の空気力学的研究
}

\author{
大津有二郎 11 - 岩田 重信 1$)$ - 竹内 健二1) - 越知美樹子1) \\ 岩田 義弘 ${ }^{1)} \cdot$ 戸田 均2) - 畔柳 久志 ${ }^{3)}$ - 中西 泰夫 ${ }^{4)}$
}

\section{Aerodynamic Studies of Voice Disorders in Vocal Attack}

\author{
Yujiro Ohtsu, Shigenobu Iwata, Kenji Takeuchi, \\ Mikiko Ochi and Yoshihiro Iwata \\ (Fujita Health University School of Medicine) \\ Hitoshi Toda \\ (Chita Kosei Hospital) \\ Hisashi Kuroyanagi \\ (Prefectual Aichi Hospital) \\ Yasuo Nakanishi \\ (Gamagori Public Hospital)
}

To clarify the phonation dynamics in voice disorders, we aerodynamically evaluated phonation during vocal attacks in 68 patients with vocal cord lesions and 12 controls with normal larynges.

The patients with polypoid cords or glottic cancer showed shortening of the time between the increase in the subglottic pressure and the vocal attack (PS-I time), the rise time, a high subglottic pressure and hard attacks.

Patients with recurrent nerve palsy showed slight shortening in the PS-I time, the rise time, a slightly higher subglottic pressure than in the control and patients with mild attacks.

Key words: vocal attack, PS-I time, rise time, air flow, subglottic pressure

\section{はじめに}

声帯病変の発声動態を検討する上で, 起声時, すなわち音声を発声する時点と音声を生じる前 の喉頭内の調節運動, ことに声帯の内転, 緊張 状態を知ることは, 極めて重要と考えられる.

そこで我々は，経鼻的声門下圧測定と当教室 で開発した発声機能解析システム $(\mathrm{PI}-100)^{1)}$
用いた発声機能を経時的に同時測定し，正常喉 頭者を対照として，病的発声の起声時における 発声動態を, 空気力学的立場から検討を加えた ので報告する。

\section{研究対象}

研究の対象症例は, 80例（男性57例，女性23 例)で(表 1), 浮腫状変性病変を主体とする,

1）藤田保健衛生大学医学部耳鼻咽喉科学教室（主任：岩田重信教授）

2）知多厚生病院耳鼻咽喉科

3）県立愛知病院耳鼻咽喉科

4）蒲郡市民病院耳鼻咽喉科 
ポリープ様声帯 8 例（男性 4 例，女性 4 例）, 硬化性病変として, 声門癌27例, らち, $\mathrm{T}_{1}$ 声 門癌12例 $T_{2}$ 声門癌11例, $T_{3}$ 声門癌 4 例, 声帯 の低緊張性病変である反回神経麻疩 33 例，らち， 正中位固定 7 例（男性 2 例，女性 5 例），副正 中位固定18例（男性13例，女性 5 例），内筋麻 瘏 8 例（男性 5 例，女性 3 例）について発声機 能を測定し，正常喉頭者12例（男性 6 例，女性 6 例）を対照として比較検討した。

\section{表 1 対象症例}

\begin{tabular}{|c|c|}
\hline 1）ポリープ様声帯 & 8例(男性：4例, 女性：4例) \\
\hline 2） $T_{1}$ 声 門 癌 & 12例 (男性：12例, 女性：0例) \\
\hline 3） $\mathrm{T}_{2}$ 声 門 癌 & 11例 (男性：11例, 女性：0例) \\
\hline 4) $\mathrm{T}_{3}$ 声 門 癌 & 4例(男性：4例, 女性：0例) \\
\hline 5）正中位固 定 & 7例 (男性：2例, 女性：5例) \\
\hline 6）副正中位固定 & 18例 (男性：13例, 女性：5例) \\
\hline 7) 内 筋 麻 盘 & 8例 (男性：5例, 女性：3例) \\
\hline 8）正 常 喉 頭 & 12例 (男性：6例, 女性：6例) \\
\hline 計 & 80例 (男性:57例, 女性:23例) \\
\hline
\end{tabular}

\section{研究方法}

発声機能に関与する各パラメーターを測定す るブロックダイアグラムを図 1 亿示す. 永島医 科器械製 PS-77 発声機能検査装置から得られ た声の強さ（音圧 : $\mathrm{dB}$ ), 声の高さ（基本周波 数 : $\mathrm{Hz})$, 呼気流率 $(\mathrm{ml} / \mathrm{sec}$.$) と \mathrm{DC}$ アンプを 介して得られる声門下圧 $\left(\mathrm{cmH}_{2} \mathrm{O}\right)$ の信号は, $\mathrm{A}-\mathrm{D}$ 変換され当教室で開発した発声機能解析 用ソフト $(\mathrm{PI}-100)^{1)}$ を用いて演算処理した。

測定法 : 被験者には楽な出し易い声の高さ， 強さで発声させる検査 ${ }^{2)}$ の意味を充分説明し理 解させた。

楽な発声で母音/a/を発声させ, 3 回測定 したらちの最も良い成績を検討のサンプルとし て採用した。

\section{研究成績}

1. 正常喉頭者の起声時の発声状態

正常喉頭者の起声時の発声動態を検討するに あたり，その代表例として，26歳，男性の成績 を図 2 に示した。

横軸に時間軸（単位：msec.）を，縦軸は上 段より呼気流率（単位 $: \mathrm{ml} / \mathrm{sec}$.), 音圧（単 位 : $\mathrm{dB}$ ), 声門下圧 (単位 : $\mathrm{cmH}_{2} \mathrm{O}$ )を示した。 この図は，起声前の発声準備状態 (prephonation) と起声時 (vocal onset), そして起声後の 音圧の膨大部 (maximum peak of amplitude envelope) までの連続的変化を示した.

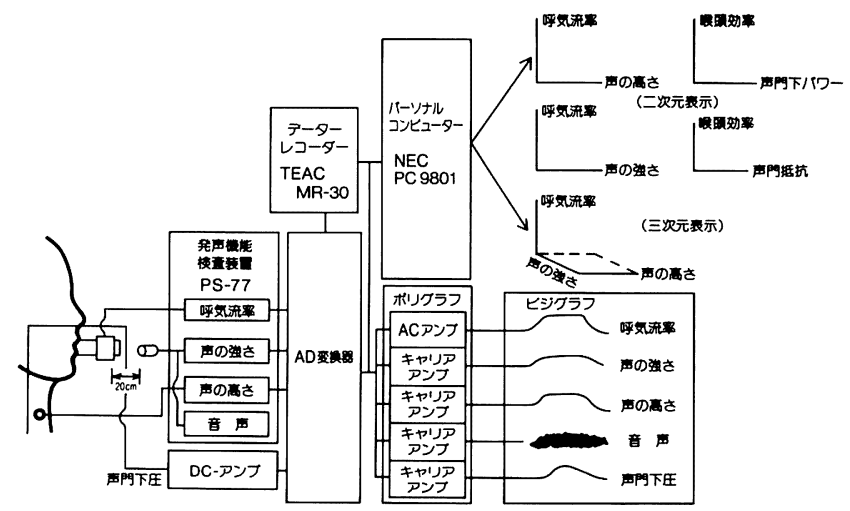

図 1 ブロックダイアグラム 
起声前, 声門下圧は徐々に上昇を始め, 6.0 $\mathrm{cmH}_{2} \mathrm{O}$ に達した時点で発声を開始し, この声 門下圧の上昇から起声時までの時間 (PS-I time) は $180 \mathrm{msec}$. であった.

呼気流率の増加は声門下圧の上昇開始後 120 msec. でピークに達しその值は $480 \mathrm{ml} / \mathrm{sec}$. で

\section{6歳 男 性}

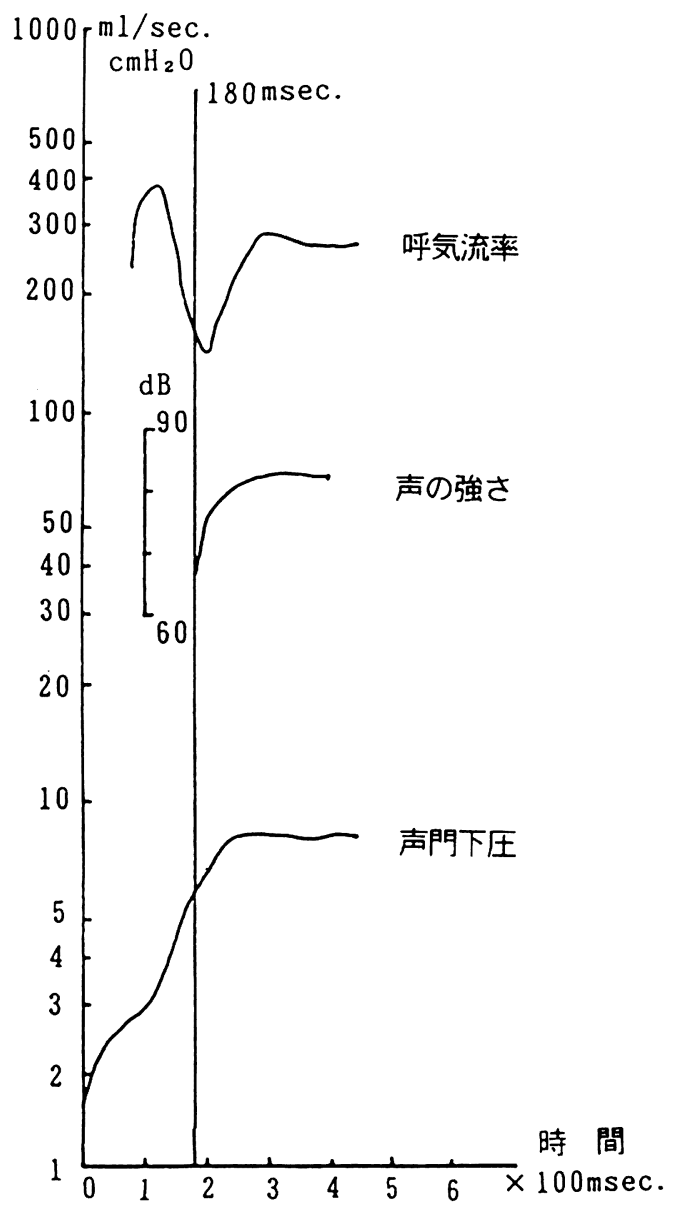

図 226 歳, 男性正常者
あった. 以後, 徐々に下降を始め $157 \mathrm{ml} / \mathrm{sec}$. の時点で起声を開始した。呼気流の流出開始か ら起声時までの時間 (U-I time) は $100 \mathrm{msec}$. で あった。

声門下圧の上昇と呼気の流出開始と同時に, 披裂部扣よび声帯は内転を始め，声帯は閉鎖状 態となって，呼気流は減少し声門下圧の上昇に つれて，声門抵抗も増加していく状態を示した。

また，音声波の振動幅は起声開始とともに増 加し, 起声時の音圧は $67 \mathrm{~dB}$ でその後, 音圧の 膨大部に達し，その時の音圧は $83 \mathrm{~dB}$ であった。 この音圧の増加開始から音圧の膨大部までの時 間を, Koike3) はたち上がり時間 (rise time) と 呼んでいるが，本例では $160 \mathrm{msec}$. であった。

次に, 起声時と音圧の膨大部に抢ける声門抵 抗, 声門下パワー, 喉頭効率の成績を表 2 に示 した.

声門抵抗は起声時で $0.38 \times 10^{2} \mathrm{cmH}_{2} \mathrm{O} / \mathrm{l} /$ $\mathrm{sec}$, 音圧の膨大部で $0.29 \times 10^{2} \mathrm{cmH}_{2} \mathrm{O} / \mathrm{l} /$ sec. と減少した.

声門下パワーは起声時で $0.92 \times 10^{6} \mathrm{erg} / \mathrm{sec}$, 音圧の膨大部では $2.32 \times 10^{6} \mathrm{erg} / \mathrm{sec}$. となり約 2.5倍に増大した。

喉頭効率は, 起声時では $0.17 \times 10^{-4}$, 膨大 部で $3.05 \times 10^{-4}$ と約18倍に増大した.

このことより, 音圧の増大に際して, 声門下 エネルギーとしての声門下パワーが効率的に音 響エネルギーに変換されている状態が，喉頭効 率の著明な増大から理解できた。

正常喉頭者12例の起声前, 起声時, 音圧の膨 大部における各パラメーターの平均值と標準偏 差を表 3 に示す.

PS-I time の平均値は $223 \pm 137 \mathrm{msec}$, U-I time の平均值は $135 \pm 105 \mathrm{msec}$, たち上がり

表 2 26歳, 男性例の各パラメーターの成績

\begin{tabular}{|c|c|c|c|c|c|c|c|c|c|c|c|c|c|c|c|c|c|}
\hline \multirow{2}{*}{ 例 } & \multirow{2}{*}{$\begin{array}{c}\text { P-I } \\
\text { 時間 } \\
\text { (msec.) }\end{array}$} & \multirow{2}{*}{\begin{tabular}{|c|}
$\mathrm{U}-1$ \\
時間 \\
(msec.)
\end{tabular}} & \multirow{2}{*}{$\begin{array}{c}\text { t:块们 } \\
\text { 時間 } \\
(\mathrm{msec} .)\end{array}$} & \multicolumn{2}{|c|}{ 音压 (dB) } & \multicolumn{3}{|c|}{ 声門下圧 $\left(\mathrm{cmH}_{2} \mathrm{O}\right)$} & \multicolumn{3}{|c|}{ 呼気流率 (ml/sec.) } & \multicolumn{2}{|c|}{$\begin{array}{c}\text { 声門抵抗 } \\
\left(\times 10^{2} \mathrm{cmH} 20 / / / \mathrm{sec} .\right)\end{array}$} & \multicolumn{2}{|c|}{$\begin{array}{l}\text { 声門下バワー } \\
(\times 106 \mathrm{erg} / \mathrm{sec} .)\end{array}$} & \multicolumn{2}{|c|}{ 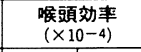 } \\
\hline & & & & 起声時 & 部 & iti & 侍 & 部 & 前 & 寺 & 大部 & 直時 & 部 & 時 & 大部 & 時 & 大部 \\
\hline$x$ & 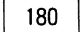 & U & 100 & $0 \gamma$ & & & & & & & & & 0.29 & & 2.32 & .17 & 3.05 \\
\hline
\end{tabular}


時間の平均值は $181 \pm 109 \mathrm{msec}$. であった。 音 圧は起声時 $66 \mathrm{~dB}$ で, 膨大部では $79 \mathrm{~dB}$ と増大 し，その際，声門下圧の平均值は起声前で 1.4 $\mathrm{cmH}_{2} \mathrm{O}$, 起声時で $4.0 \mathrm{cmH}_{2} \mathrm{O}$ と約 3 倍, 膨大 部では $5.8 \mathrm{cmH}_{2} \mathrm{O}$ と約 4 倍に増加した.

呼気流率の平均值は起声前は $66 \mathrm{ml} / \mathrm{sec}$, , 起声時で $144 \mathrm{ml} / \mathrm{sec}$. と約 2 倍, 膨大部では 197 $\mathrm{ml} / \mathrm{sec}$. と約 3 倍に増加し, 声門抵抗は起声時 で $0.38 \times 10^{2} \mathrm{cmH}_{2} \mathrm{O} / 1 / \mathrm{sec}$, 膨大部で $0.35 \times$ $10^{2} \mathrm{cmH}_{2} \mathrm{O} / 1 / \mathrm{sec}$. と軽度減少したが，声門下 パワーのそれは起声時で $0.62 \times 10^{6} \mathrm{erg} / \mathrm{sec}$, 膨大部では $2.56 \times 10^{6} \mathrm{erg} / \mathrm{sec}$. と約 4 倍に増大 した．その結果，喉頭効率は起声時で $0.91 \times$ $10^{-4}$ で膨大部では $11.03 \times 10^{-4}$ と約 12 倍と著 明増大した。

以上より正常発声では起声開始までの 223 msec. の間に披裂部の内転運動叔よび声門閉 鎖が起こり，声門下圧の上昇と僅かに遅れて， 呼気の流出が起こり起声に至る, 以後声門抵抗 は減少し, 声門下圧と呼気流率の増加による声 門下パワーの増大によって音圧のピークに達し， その際の声帯における音響エネルギーへの变換
効率は著明に良好であることが理解された。

2. 病的発声の起声時に括ける発声動態

1）ポリープ様声帯

ポリープ様声帯 8 例の各パラメーターの平均 值と標準偏差を表 3 に示した。

PS-I time は $120 \mathrm{msec}$, U-I time は 80 msec.，たち上がり時間は $190 \mathrm{msec}$.であった。 正常喉頭者の成績に比べ PS-I time は50\%に短 縮し，U-I timeは は0\% と短縮したが，たち上が り時間は正常喉頭と差はなかった。

音圧は起声時, 膨大部でそれぞれ, $66 \mathrm{~dB} ， 80$ $\mathrm{dB}$ で正常例の平均值と差はなかった.

声門下圧は起声前 $1.8 \mathrm{cmH}_{2} \mathrm{O}$ で起声時は $8.4 \mathrm{cmH}_{2} \mathrm{O}$, 音圧の膨大部では $11.4 \mathrm{cmH}_{2} \mathrm{O}$ と 増大し, 正常例に比べ起声前で1.3倍, 起声時 で 2 倍，膨大部では約 2 倍に増加していた。

呼気流率は起声前, 起声時, 膨大部において, それぞれ $57 \mathrm{ml} / \mathrm{sec} ., 134 \mathrm{ml} / \mathrm{sec} ., 360 \mathrm{ml} / \mathrm{sec}$. で正常例のそれらの成績と比べ, 起声前で, 起 声時で僅かに減少し, 膨大部では約 2 倍に増加 していた.

声門抵抗値は起声時, 膨大部での平均値は,

表 3 疾患別の各パラメーターの平均値と標準偏差

\begin{tabular}{|c|c|c|c|c|c|c|c|c|c|c|c|c|c|c|c|c|c|}
\hline \multirow{2}{*}{$\begin{array}{c}\text { 症 例 } \\
\mathrm{n}=80\end{array}$} & \multirow{2}{*}{$\begin{array}{c}\mathrm{P}-\mathrm{I} \\
\text { 時間 } \\
\text { (msec.) }\end{array}$} & \multirow{2}{*}{$\begin{array}{c}\mathrm{U}-1 \\
\text { 時間 } \\
\text { (msec.) }\end{array}$} & \multirow{2}{*}{ 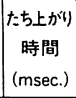 } & \multicolumn{2}{|c|}{ 音压 (dB) } & \multicolumn{3}{|c|}{ 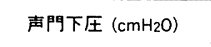 } & \multicolumn{3}{|c|}{ 呼気流率 $(\mathrm{ml} / \mathrm{sec}$.) } & \multicolumn{2}{|c|}{\begin{tabular}{c|c|} 
声門抵抗 \\
$(\times 102 \mathrm{cmH} 20 / / / \mathrm{sec})$. \\
\end{tabular}} & \multicolumn{2}{|c|}{\begin{tabular}{l|} 
声門下パワー \\
$(\times 106 \mathrm{erg} / \mathrm{sec})$.
\end{tabular}} & \multicolumn{2}{|c|}{ 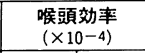 } \\
\hline & & & & 起声時 & 脚大部 & 起声前 & 起声時 & 膨大部 & 起声前 & 起声時 & 膨大部 & 起声時 & 膨大部 & 起声時 & 膨大部 & 起声時 & 膨大部 \\
\hline 正常喉頭 & 223 & 135 & 181 & 66 & 79 & 1.4 & 4.0 & 5.8 & 66 & 144 & 197 & 0.38 & 0.35 & 0.62 & 2.56 & 0.91 & 11.03 \\
\hline$n=12$ & 137 & 105 & 109 & 2 & 4 & 0.3 & 1.9 & 2.9 & 62 & 96 & 109 & 0.25 & 0.17 & 0.61 & 4.50 & 1.17 & 18.32 \\
\hline ポリーブ様声帯 & 120 & 80 & 190 & 66 & 80 & 1.8 & 8.4 & 11.4 & 57 & 134 & 360 & 0.89 & 0.49 & 0.99 & 2.79 & 0.20 & 2.20 \\
\hline$n=8$ & 118 & 100 & 84 & 3 & 4 & 0.5 & 3.3 & 3.1 & 29 & 70 & 66 & 0.70 & 0.28 & 0.39 & 0.66 & 0.16 & 3.01 \\
\hline T，声門癌 & 208 & 120 & 138 & 66 & 80 & 1.3 & 15.4 & 17.9 & 34 & 96 & 190 & 2.53 & 1.58 & 1.44 & 3.44 & 1.82 & 7.01 \\
\hline$n=12$ & 104 & 103 & 53 & 5 & 5 & 0.4 & 13.3 & 12.9 & 25 & 56 & 134 & 3.72 & 1.93 & 1.32 & 3.66 & 5.10 & 9.84 \\
\hline $\mathrm{T}_{2}$ 声門㾞 & 272 & 98 & 152 & 64 & 77 & 1.8 & 15.5 & 20.7 & 47 & 149 & 266 & 3.11 & 3.65 & 2.48 & 5.40 & 0.25 & 1.03 \\
\hline$n=11$ & 233 & 109 & 107 & 3 & 5 & 1.2 & 6 & 10.2 & 45 & 147 & 204 & 3.95 & 5.83 & 3.82 & 4.24 & 0.46 & 1.18 \\
\hline$T_{3}$ 声門癌 & 140 & 50 & 200 & 64 & 75 & 1.8 & 8.4 & 13.9 & 34 & 110 & 228 & 1.40 & 1.29 & 0.84 & 3.98 & 0.31 & 0.68 \\
\hline$n=4$ & 37 & 41 & 48 & 2 & 4 & 0.9 & 2.4 & 6.9 & 21 & 103 & 179 & 0.76 & 1.09 & 0.70 & 4.81 & 0.43 & 0.24 \\
\hline 正中位固定 & 160 & 108 & 168 & 67 & 76 & 1.4 & 4.5 & 7.0 & 88 & 228 & 326 & 0.60 & 0.31 & 1.12 & 2.79 & 2.49 & 4.69 \\
\hline$n=7$ & 97 & 75 & 109 & 4 & 2 & 0.5 & 1.9 & 3.4 & 86 & 225 & 280 & 0.74 & 0.17 & 1.19 & 3.11 & 4.86 & 8.61 \\
\hline 副正中位固定 & 171 & 104 & 186 & 64 & 76 & 1.7 & 5 & 10.2 & 86 & 349 & 503 & 0.23 & 0.22 & 1.72 & .96 & 0.17 & 1.42 \\
\hline$n=18$ & 171 & 106 & 85 & 3 & 7 & 0.6 & 4.6 & 5.7 & 80 & 231 & 265 & 0.58 & 0.46 & 1.70 & 4.42 & 0.23 & 3.67 \\
\hline 内筋麻㾴 & 140 & 102 & 202 & 65 & 79 & 1.6 & 6.8 & 10.6 & 113 & 298 & 412 & 0.34 & 0.33 & 2.27 & 5.31 & 1.74 & 7.66 \\
\hline$n=8$ & 63 & 71 & 130 & 4 & 6 & 0.6 & 3.8 & 5.7 & 84 & 203 & 279 & 0.23 & 0.15 & 2.61 & 4.77 & 4.36 & 16.75 \\
\hline
\end{tabular}


$0.89 \times 10^{2} \mathrm{cmH}_{2} \mathrm{O} / 1 / \mathrm{sec} ., \quad 0.49 \times 10^{2} \mathrm{cmH}_{2} \mathrm{O}$ $/ 1 / \mathrm{sec}$. となり正常例に比し, 起声時で約 2 倍, 膨大部で1.4倍に増加していた。

このことは, 声帯の浮腫状変化による声門抵 抗の増加は起声後から膨大部に至る音圧増加に 際し, 声門下圧と呼気流率を共に増加させてい ると理解できた.

声門下パワーは起声時で $0.99 \times 10^{6} \mathrm{erg} / \mathrm{sec}$. 膨大部で $2.79 \times 10^{6} \mathrm{erg} / \mathrm{sec}$. と正常例に比べ, 約1.5亿増加し, 喉頭効率は起声時, 膨大部そ れぞれ， $0.2 \times 10^{-4}, 2.2 \times 10^{-4}$ とともに, 正常 発声のそれに比べ約20\%に減少しており，变換 効率の低下が窥えた。

2) $T_{1}$ 声門癌

$\mathrm{T}_{1}$ 声門癌12例の各パラメーターの平均値と 標準偏差を表 3 に示した.

PS-I time，U-I time，たち上がり時間の成績 はそれぞれ, $208 \mathrm{msec},, 120 \mathrm{msec}, 138 \mathrm{msec}$. で，正常例の成績に比しそれぞれ短縮した。

音圧は起声時で $66 \mathrm{~dB}$, 膨大部で $80 \mathrm{~dB}$ で, 声門下圧は, 起声前, 起声時, 膨大部でそれぞ れ $1.3 \mathrm{cmH}_{2} \mathrm{O}, 15.4 \mathrm{cmH}_{2} \mathrm{O}, 17.9 \mathrm{cmH}_{2} \mathrm{O}$ を示 し, 正常例と比べ起声時で約 4 倍, 膨大部で約 3 倍に増加していた。

呼気流率は正常者に比し起声前, 起声時, 膨 大部でそれぞれ, $34 \mathrm{ml} / \mathrm{sec} ., 96 \mathrm{ml} / \mathrm{sec},, 190 \mathrm{ml}$ /sec. と減少し, 声門抵抗は起声時, 膨大部で, $2.53 \times 10^{2} \mathrm{cmH}_{2} \mathrm{O} / 1 / \mathrm{sec}$. $1.58 \times 10^{2} \mathrm{cmH}_{2} \mathrm{O} /$ $1 / \mathrm{sec}$. で正常例の6.6倍, 4.5倍となった.

声門下パワーは起声時, 膨大部で, $1.44 \times$ $10^{6} \mathrm{erg} / \mathrm{sec}$, $3.44 \times 10^{6} \mathrm{erg} / \mathrm{sec}$. と増大した。

喉頭効率は起声時で $1.82 \times 10^{-4}$, 膨大部で $7.01 \times 10^{-4}$ と正常例に比べ，起声時で 2 倍に 拡大したが，膨大部では63\%に減少していた。

$3 . \mathrm{T}_{2}$ 声門癌

$\mathrm{T}_{2}$ 声門癌11例の各パラメーターの平均值と 標準偏差を表 3 に示した.

PS-I time, U-I time，たち上がり時間はそれ ぞれ, $272 \mathrm{msec}$, $98 \mathrm{msec}$, $152 \mathrm{msec}$.となり 正常例と比較すると PS-I time, たち上がり時
間は, 1.2倍, 1.3倍と延長したが, U-I time は70 $\%$ と短くなった.

声門下圧は起声前, 起声時, 膨大部でそれぞ れ, $1.8 \mathrm{cmH}_{2} \mathrm{O}, 15.5 \mathrm{cmH}_{2} \mathrm{O}, 20.7 \mathrm{cmH}_{2} \mathrm{O}$ と 正常例の1.3倍, 4 倍, 3.5 倍と増大した. 声門 抵抗は起声時で $3.11 \times 10^{2} \mathrm{cmH}_{2} \mathrm{O} / 1 / \mathrm{sec}$., 膨 大部で $3.65 \times 10^{2} \mathrm{cmH}_{2} \mathrm{O} / 1 / \mathrm{sec}$. で正常例のそ れの 8 倍, 10倍に増大し, 声門下パワーは起声 時, 膨大部で $2.48 \times 10^{6} \mathrm{erg} / \mathrm{sec}, \quad 5.40 \times 10^{6}$ $\mathrm{erg} / \mathrm{sec}$. と正常例の 4 倍, 2 倍に増大したが, 喉頭効率は起声時で $0.25 \times 10^{-4}$, 膨大部で $1.03 \times 10^{-4}$ と正常例の約 $20 \% ， 9 \%$ と著明に 低下した.

4) $\mathrm{T}_{3}$ 声門癌

$\mathrm{T}_{3}$ 声門癌 4 例の各パラメーターの平均值と 標準偏差を表 3 に示した。

PS-I time, U-I time，たち上がり時間の成績 は，それぞれ $140 \mathrm{msec}, 50 \mathrm{msec}, 200 \mathrm{msec}$. と正常例と比較し PS-I time は 1.2 倍延長し, U-I time は30\%に短縮し，たち上がり時間は正 常範囲内であった。

音圧は起声時, 膨大部でそれぞれ $64 \mathrm{~dB}, 75$ $\mathrm{dB}$ で声門下圧は, 起声前, 起声時, 膨大部で $1.8 \mathrm{cmH}_{2} \mathrm{O}, 8.4 \mathrm{cmH}_{2} \mathrm{O}, 13.9 \mathrm{cmH}_{2} \mathrm{O}$ で正常 例の1.3倍, 2 倍, 2.4 倍と増加した.

呼気流率は起声前, 起声時, 膨大部で, 34 $\mathrm{ml} / \mathrm{sec}$, $110 \mathrm{ml} / \mathrm{sec},, 228 \mathrm{ml} / \mathrm{sec}$. で声門抵抗 は起声時, 膨大部で $1.40 \times 10^{2} \mathrm{cmH}_{2} \mathrm{O} / \mathrm{l} / \mathrm{sec}$, $1.29 \times 10^{2} \mathrm{cmH}_{2} \mathrm{O} / 1 / \mathrm{sec}$. とともに正常例の 3.7 倍に増大した。

声門下パワーは起声時, 膨大部で $0.84 \times 10^{6}$ $\mathrm{erg} / \mathrm{sec} ., 3.98 \times 10^{6} \mathrm{erg} / \mathrm{sec}$. となり喉頭効率 は起声時と膨大部では $0.31 \times 10^{-4}, 0.68 \times 10^{-4}$ と正常例の $30 \%$ と $6 \%$ とに著明減少した.

以上より, 声門癌では PS-I time の声門閉鎖 期を短くし, 高い声門抵抗に対して, 声門下圧 を正常例の約 $2 \sim 3$ 倍に増加させ, また, 比較 的短いたち上がり時間をもって一気に音圧の膨 大部に達することを示した。 また，腫瘍の声門 に占める割合や, 声帯の stiffness の増大によ 
る声門抵抗の増加で呼気流率の減少がみられた。 声門下パワーは正常例の約 $2 \sim 4$ 倍に増大して いた。

喉頭効率は声帯に対し, 腫瘍の影響の大きな $\mathrm{T}_{2}, \mathrm{~T}_{3}$ 症例となると低い值を示し, 変換効率 の低下を示した.

5 ）一側反回神経麻痺

(1) 正中位固定

正中位固定 7 例の各パラメーターの平均值と 標準偏差を表 3 に示した.

PS-I time，U-I time，たち上がり時間はそれ ぞれ $160 \mathrm{msec}$, $108 \mathrm{msec}$, $168 \mathrm{msec}$. と正常 例の $70 \% ， 80 \% ， 90 \%$ と短縮した。

声門下圧は起声前, 起声時, 膨大部で 1.4 $\mathrm{cmH}_{2} \mathrm{O}, 4.5 \mathrm{cmH}_{2} \mathrm{O}, 7.0 \mathrm{cmH}_{2} \mathrm{O}$ で起声前, 起 声時は正常範囲であったが, 膨大部では1.2倍 と僅かに増大し, 呼気流率は起声前, 起声時, 膨大部で $88 \mathrm{ml} / \mathrm{sec}$, $228 \mathrm{ml} / \mathrm{sec}$, $326 \mathrm{ml} / \mathrm{sec}$. となり正常の 1.3 倍, 1.6 倍, 1.7 倍に増加した. 声門抵抗は起声時, $0.60 \times 10^{2} \mathrm{cmH}_{2} \mathrm{O} / 1 / \mathrm{sec}$. で正常例の 1.5 倍に増大したが，膨大部では $0.31 \times 10^{2} \mathrm{cmH}_{2} \mathrm{O} / 1 / \mathrm{sec}$. と約 $50 \%$ に減少した. 声門下パワーは起声時, 膨大部で $1.12 \times 10^{6}$ $\mathrm{erg} / \mathrm{sec}$, $2.79 \times 10^{6} \mathrm{erg} / \mathrm{sec}$. で起声時は正常 の1.8倍増であったが，膨大部では正常範囲で あった。

喉頭効率は起声時, 膨大部で $2.49 \times 10^{-4}, 4.6$ $9 \times 10^{-4}$ で起声時は2.7倍となり, 膨大部では 42\%に縮小した。

（2）副正中位固定

副正中位固定 7 例の各パラメーターの平均值 と標準偏差を表 3 に示した。

PS-I time, U-I time, は $171 \mathrm{msec}, 104$ msec., で正常例の70\%，77\%に短縮し，たち 上がりの時間は $186 \mathrm{msec}$. で正常範囲内であっ た.

声門下圧は起声前, 起声時, 膨大部で 1.7 $\mathrm{cmH}_{2} \mathrm{O}, 5.6 \mathrm{cmH}_{2} \mathrm{O}, 10.2 \mathrm{cmH}_{2} \mathrm{O}$ で正常例の 1.2 倍, 1.4 倍, 1.7 倍に増加した.

呼気流率は起声前, 起声時, 膨大部で 86 $\mathrm{ml} / \mathrm{sec} ., 349 \mathrm{ml} / \mathrm{sec} ., 503 \mathrm{ml} / \mathrm{sec}$. でそれぞれ, 正常の1.3倍, 2.4倍, 2.5倍に増加した.

声門抵抗は起声時, 膨大部で $0.23 \times 10^{2}$ $\mathrm{cmH}_{2} \mathrm{O} / 1 / \mathrm{sec}$, $0.22 \times 10^{2} \mathrm{cmH}_{2} \mathrm{O} / 1 / \mathrm{sec}$. で, ともに正常の $60 \%$ に減少した. 声門下パワーは起声時, 膨大部で $1.17 \times 10^{6}$ $\mathrm{erg} / \mathrm{sec} ., 4.96 \times 10^{6} \mathrm{erg} / \mathrm{sec}$. で正常例の 2.7 倍, 2 倍に増大し, 喉頭効率は起声時, 膨大部で, $0.17 \times 10^{-4}, 1.42 \times 10^{-4}$ で正常例の $18 \%, 12 \%$ に著明に減少した.

以上より, 声帯の低緊張性病変である反回神 経麻痺では声門閉鎖期の PS-I time は正常より 軽度短縮し, 声門下圧の増加開始後, 僅かに遅 れて, 正常例よりも約 $1.2 \sim 1.7$ 倍の呼気の流出 が起こり，また正常例よりも1.2倍程高い声門 下圧をもって起声に至った。

声門抵抗は声帯のレベル差のある正中位固定 では，起声時に僅かに正常例よりも高い值を示 したが，音圧の膨大部に拈いては低下していた。 発声時の声門間隙の大きな副正中位固定では起 声時, 膨大部と正常よりも著明に減少した. 声 帯筋の萎縮による声門間隙をみた内筋麻痺例で は起声時, 膨大部を通して声門抵抗の僅かな低 下を示した。

声門下パワーは正常とほぼ同じ音圧を維持す るために，声門下圧の増大と呼気流率の著明増 加を反映し, 起声時, 膨大部共に約 $2 \sim 4$ 倍に 増加した。

喉頭効率は声門下パワーの増大にも拘らず音 圧に反映されなかった副正中位固定例は著明に 縮小し，正中固定，内筋麻瘏は起声時では約 2 倍程に拡大寸るも，音圧の膨大部では，呼気流 率の漏出が影響し，約 $40 \sim 70 \%$ と变換効率の低 下が窺えた。

\section{考察}

起声 (vocal attack) は, 声の出し始めに声帯 が呼吸位から発声位に移行する部位を示し発声 法により, 軟起声 (soft attack), 硬起声 (hard attack), 気息起声 (breathy attack) の 3 つに分類 されている4). 
岩田 ${ }^{5)}$ ，廣戸ら ${ }^{6)}$ は起声前， $170 \mathrm{msec}$. から $190 \mathrm{msec}$. で声門下圧は上昇を始め，声門下圧 が, $2.0 \mathrm{cmH}_{2} \mathrm{O}$ から $3.0 \mathrm{cmH}_{2} \mathrm{O}$ に達すると発 声を開始し, その後も声門下圧は増大し, 発声 開始後 $90 \mathrm{msec}$. から $130 \mathrm{msec}$. にて声門下圧 は最大となり（多くは $4.0 \mathrm{cmH}_{2} \mathrm{O}$ )， また終声 で $3.0 \mathrm{cmH}_{2} \mathrm{O}$ 以下になると発声は終了すると 報告した．今回我々が検討した，正常例の成績 では声門下圧の上昇から起声時までの時間 (PS-I time) は $223 \mathrm{msec}$. で起声時の声門下圧は $4.0 \mathrm{cmH}_{2} \mathrm{O}$ で，また起声開始後，音圧の膨大 部までの時間 (rise time) は $181 \mathrm{msec}$.でその時 の声門下圧は $5.8 \mathrm{cmH}_{2} \mathrm{O}$ で岩田5) の報告と注 ぼ同様の結果であった。

また，浅野7)は生理学的起声を検討し, PS-I time は硬起声は $113 \pm 10.8 \mathrm{msec}$, 軟起声で $284 \pm 45.8 \mathrm{msec}$, 気息起声で $216 \pm 16.8 \mathrm{msec}$. であり，起声時の声門下圧は軟起声で $2.9 \pm$ $0.1 \mathrm{cmH}_{2} \mathrm{O}$, 硬起声で $12.6 \pm 0.6 \mathrm{cmH}_{2} \mathrm{O}$, 気息 起声で $4.6 \pm 0.1 \mathrm{cmH}_{2} \mathrm{O}$ で呼気流率は軟起声で $195 \mathrm{ml} / \mathrm{sec}$, 硬起声で $3 \mathrm{ml} / \mathrm{sec}$, , 気息起声で $937 \mathrm{ml} / \mathrm{sec}$. であったと報告している.

我々の正常例の起声時の呼気流率は 144 $\mathrm{ml} / \mathrm{sec}$. であり浅野7)の軟起声の範囲にあった。

声帯の浮腫状変性であるポリープ様声帯と硬 化性病変である声門癌 $\mathrm{T}_{1}, \mathrm{~T}_{2}, \mathrm{~T}_{3}$ の PS-I time は正常例のそれの50～90\%に短縮した. また起 声時の声門下圧は正常例の約 $2 \sim 4$ 倍に増大し, 起声時の呼気流率は約60 90\% と減少し, 硬起 声の状態を示した。

声帯の低緊張性病変である反回神経麻痺例の PS-I time は正常例の約 60〜 70\%に短縮した. 起声時の声門下圧は約1.4 1.7倍と軽度増大し， 起声時の呼気流率は約1.6 2.4倍に増加し, 軟 起声に類似した状態を示した。

Koike ${ }^{3)}$ は起声部に注目し，起声時に扣ける 音声波の上昇開始から音圧のピーク(音声波の膨 大部 : maximum peak of amplitude envelope) までの時間をたち上がり時間 (rise time) とし， 生理的な発声におけるたち上がり時間は軟起声
では長く（平均約 $260 \mathrm{msec}$.) で硬起声では短 く(平均約 $30 \mathrm{msec}$ ), 気息起声では平均約 148 msec. で喉頭の悪性腫瘍ではしばしば硬起声 に近い状態を示すと報告した。我々の正常例の たち上がり時間は $181 \mathrm{msec}$.であった。

ポリープ様声帯, 声門癌例のたち上がり時間 は正常例の約 $80 \%$ に短縮したが，Koike の報 告3) ほどの短縮は示さなかった.

反回神経麻疩例では正常例の約 $90 \%$ の短縮な いし正常とほぼ同じであった。

声門下エネルギーの源である声門下圧は，ポ リープ様声帯, 声門癌例では声帯に占める病変 の割合や, 声帯の stiffness, 声帯の粘膜変化に よる高い声門抵抗に対し, 起声時, 膨大部共に 正常例の約 $2 \sim 4$ 倍に増加していた. 反回神経 麻痺例では呼気流率の増加をみるが，声門下土 ネルギーとして充分に反映されないため, 声門 下圧は正常例の約1.2〜1.7倍程増加した.

黒木8) は起声時に抢ける声門下圧の変動につ いて検討し, 起声時の声門下圧は正常で 10 $\mathrm{cmH}_{2} \mathrm{O}$, 声門癌で $26 \mathrm{cmH}_{2} \mathrm{O}$, 片側反回神経麻 痺で $9 \mathrm{cmH}_{2} \mathrm{O}$ であったと報告し, 我々の成績 も同様の傾向を示した.

声門抵抗はポリープ様声帯, 声門癌では正常 例の約 $2 \sim 8$ 倍に増大して括り, $\mathrm{T}_{2}>\mathrm{T}_{1}>\mathrm{T}_{3}$ $>$ ア゚リープ様声帯の順に高い值を示し, 声帯に 占める腫瘤の割合, stiffness の増加の程度に比 例していた。

反回神経麻痺例では発声時の声門間隙の大き さに比例し, 副正中位固定 $>$ 内筋麻㽻 $>$ 正中位 固定の順に声門抵抗の低下を示し，正常例の約 60〜90\%に減少した.

声門下パワーは, ポリープ様声帯, 声門癌で は声門下圧の増加を反映し, 正常例の約 $2 \sim 4$ 倍に増大し, 反回神経麻舫例では約 $2 \sim 4$ 倍に 増大した。

喉頭効率はポリープ様声帯, 声門癌, 反回神 経麻痺共に低值を示し, 腫瘤性病変では声帯に 占める病変の大きなもの程その低下は著明であ り，また低緊張性病変では発声時の声門間隙の 
大きな例程, 喉頭効率の悪化が顕著であった.

\section{結 語}

1. 当教室で開発した発声機能解析装置によ る発声機能と経鼻的声門下圧を同時測定し, 起 声時に扣ける発声動態を, 正常例を対照として 声帯の腫瘤性病変と低緊張性病変について検討 した。

2. 腫瘤性病変の声門下圧の上昇から起声時 までの時間 (PS-I time) と, 起声時から音圧の 膨大部までの時間（たち上がり時間）は，正常 例に比して短縮し硬起声発声を示した.

3. 低緊張性病変では PS-I time とたち上が り時間は正常例に比べ軽度短縮し, 呼気流率の 増加は著明で軟起声の傾向を示した。

4.喉頭効率は腫瘤性病変では声帯に占める 病変の大きなもの程, また低緊張性病変では発 声時の声門間隙の大きな例程, その悪化は顕著 であった。

\section{参考文献}

1）岩田重信, 大津有二郎, 小島秀嗣, 他 : 発声機 能自動解析システム (PI-100) とついて. 音声言 語医 $32 ： 406 \sim 412,1991$.

2) 平野実, 斉藤成司, 澤島政行, 他: 発声機能 検查施行上，ガイドラインについて。音声言語 医 $23: 164 \sim 167,1982$.

3) Koike $Y$ : Experimental studies on vocal attack. 耳鼻臨床 $60: 663 \sim 688,1967$.

4) 平野 実 : 喉頭の生理. 臨床耳鼻咽喉科 - 頭頸 部外科全書 $10 \mathrm{~A}$ (斉藤成司, 日野原正編)。61 ～63頁, 金原出版, 東京, 1986 .

5）岩田重信 : 空気力学的にみた発声障害の臨床. 音声言語医 $21 ： 168 \sim 174,1980$.

6）廣戸幾一郎：発声機構の面よりみた喉頭の病態 生理. 耳鼻臨床 $59: 229 \sim 292,1966$.

7）浅野公子 : 起声に関する空気力学的研究. 金沢 十全医誌 $80: 617 \sim 631,1971$.

8）黑木康二 : 発声時の声門下圧に関する研究. 耳 鼻 $15: 54 \sim 74,1969$.

(別刷請求先 : 岩田重信 ₹470 豊明市沓掛町田楽ヶ䆶1-98 藤田保健葦生大学医学部耳鼻咽喉科学教室) 